\title{
HENK VERHEUL (1947-2007)
}

IN MEMORIAM

Op 27 januari 2007 overleed volkomen onverwacht Henk Verheul, medewerker van het Nederlands Instituut voor Beeld en Geluid en oprichter van het Smalfilmmuseum. Dat amateurfilm de laatste jaren zowel bij programmamakers als bij academici in Nederland erkenning heeft gevonden als een belangrijke bron, is vrijwel geheel zijn verdienste geweest.

Verheul die zelf een actief hobbyfilmer was, startte in de jaren tachtig met het verzamelen van alles wat met amateurfilm te maken had. Hiertoe richtte hij met een aantal medestanders in I985 de Stichting Smalfilmmuseum op. Hij zocht onmiddellijk de publiciteit op, zoals bleek uit een (bij Beeld en Geluid bewaard gebleven) optreden in het TV-programma SPREKERSHOE K in maart I986. In eerste instantie werd het verzamelde materiaal bij hem thuis op zolder opgeslagen. Later vond hij opslagruimten op verschillende locaties in het Gooi. Hij wist zijn organisatietalenten, waarvan hij als studiochef bij de Nos dagelijks blijk gaf, uitstekend in te zetten bij de verschillende activiteiten van het Smalfilmmuseum. Zo stuurde hij een team van vrijwilligers aan, organiseerde maandelijkse filmvertoningen, richtte tentoonstellingen in en gaf een nieuwsbrief uit. Maar het belangrijkste was het onderhouden van een netwerk van amateurfilmers in den lande, dat een groeiende stroom aan acquisities genereerde. Verheul beperkte zich niet tot celluloid maar verzamelde ook camera's en projectoren, tijdschriften en boeken, affiches, folders en foto's. Overigens gold zijn liefde niet alleen de amateurfilm. Vele jaren organiseerde hij samen met zijn vrouw Els de Blaricumse Filmdagen, een festival voor kwaliteitsfilms. Ook was hij betrokken bij het Festikon, een door het Nederlands Film Instituut georganiseerd festival van vormingsfilms, dat eerst in het Singer in Laren en later in de Amsterdamse Meervaart werd gehouden. Toen het Festikon in I988 overging in het International Documentary Filmfestival Amsterdam, was Verheul de eerste jaren verantwoordelijk voor de techniek, wat met alle verschillende formaten bepaald geen sinecure was. Maar Verheul bleef onder alle omstandigheden rustig en beleefd.

Als gevolg van een grote reorganisatie bij de Nos overbodig geworden, trad Verheul begin jaren negentig in dienst bij het Audiovisueel Archiefcentrum (AVAC) van de мов. De ervaringen die hij daar opdeed bij de conservering van de Polygooncollectie, kwamen hem goed van pas bij zijn eigen Smalfilmmuseum. 


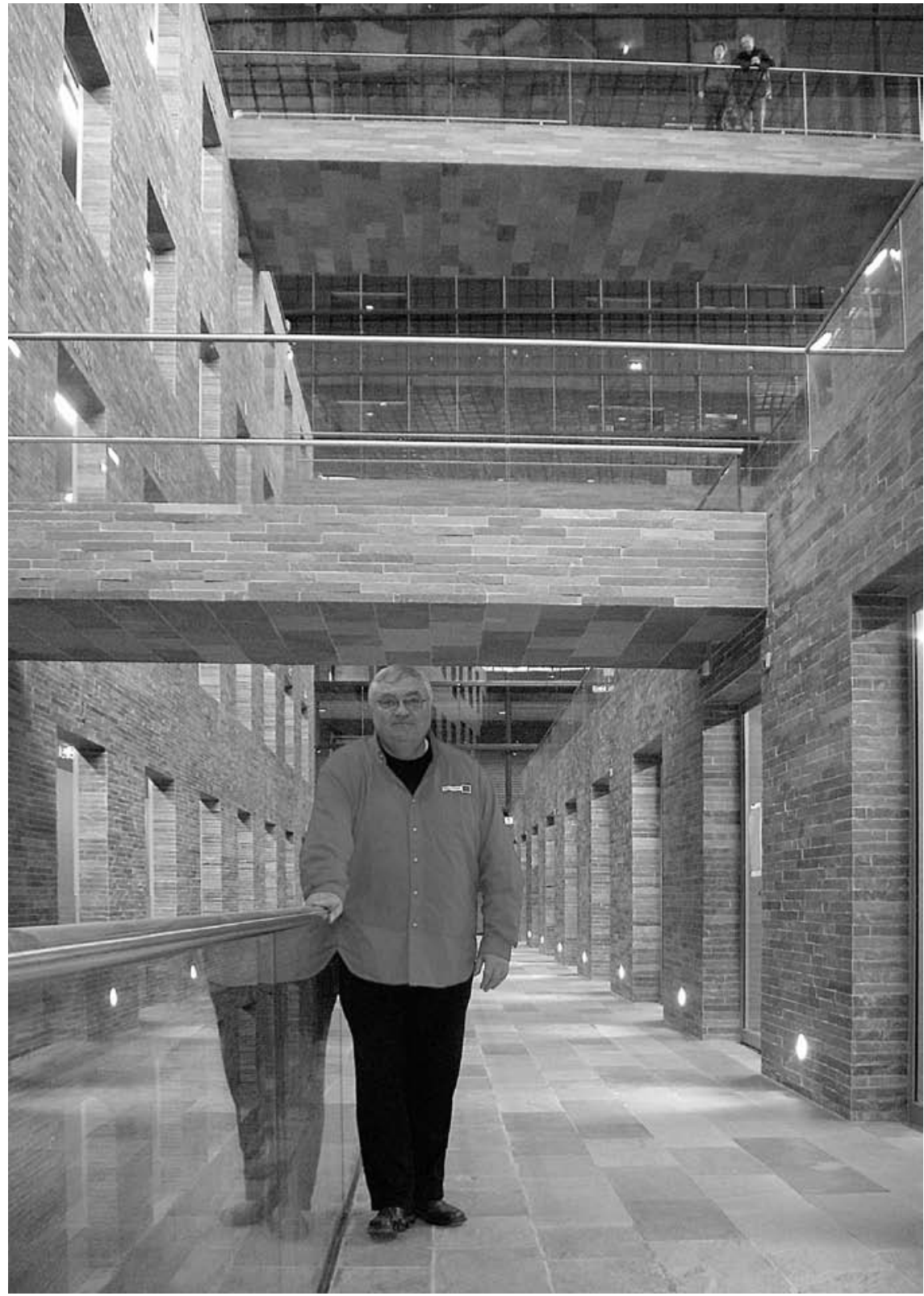

Want zowel aan de ontsluiting van het materiaal als aan de conservering ervan stelde Verheul hoge eisen. Zo liet hij een relationele database ontwerpen, waarmee het mogelijk was om met één vraag verschillende collecties met verschillend materiaal te doorzoeken. Zo werd het mogelijk om van een maker niet alleen te weten te komen welke films er aanwezig waren maar ook de camera's, boeken en tijdschriften. Zo kon een compleet beeld gekregen worden van de 
technische condities en de kennis van de betrokken maker. Hiermee was Verheul professionele instellingen als het Filmmuseum en Beeld en Geluid (tussen I997 en 200I nog NAA geheten) voor.

Subsidies van de Mondriaan Stichting en later ook van andere fondsen stelden het Smalfilmmuseum rond 2000 in staat een begin te maken met de conservering van de films. Zo werd steeds meer materiaal op Digibeta toegankelijk voor hergebruik. Vaak aangemoedigd door Verheul zelf, vond dan ook een groeiend aantal (televisie)makers de weg naar de collecties. Dat resulteerde in films die voor een deel of in hun geheel bestonden uit materiaal dat afkomstig was uit de collecties van het Smalfilmmuseum, zoals DE MAALSTroom (I997) van Peter Forgacs, met opnamen van de Joodse familie Peereboom, of EENDJES VOEREN $(2005)$ van Eugenie Jansen, waarin dit ritueel aan de hand van beelden uit heel veel verschillende amateurfilms wordt geïllustreerd. Natuurlijk wist ook het televisieprogramma ANDERE TIJDEN de weg naar het Smalfilmmuseum te vinden. In de loop van de jaren negentig trok het ook de belangstelling van academici. Het proefschrift van Susan Aasman, Rituelen van huiselijk geluk (2004), had niet zonder het door Verheul verzamelde materiaal geschreven kunnen worden.

Al langer liep Verheul rond met het plan om de collecties van het Smalfilmmuseum onder te brengen bij een professionele instelling waar een duurzaam behoud was gegarandeerd. In 2006 droeg hij al het materiaal over aan Beeld en Geluid. Tegelijk was hij al weer druk bezig met plannen voor nieuwe activiteiten. Daartoe had hij de Stichting Amateurfilm opgericht, die de maandelijkse vertoningen in het Filmtheater Hilversum moest voortzetten, en bovendien de organisatie van de jaarlijkse Dag van de Amateurfilm voor haar rekening nemen. Samen met schrijver dezes was hij van plan een publicatie te verzorgen over de films van Dick Laan die bekendheid heeft gekregen als auteur van Pinkeltje maar ook een zeer productieve amateurfilmer was. Tot slot wilde Verheul zijn vleugels internationaal uitslaan via het voorzitterschap van de Association Européenne Inédits. Maar het heeft niet zo mogen zijn. Verheul heeft een indrukwekkende nalatenschap achtergelaten. Zijn familie, collega's en vrienden zullen hem node missen.

\section{Bert Hogenkamp}

